\title{
Disposition of two names in Almeidea (Rutaceae)
}

\author{
Milton Groppo ${ }^{1}$ and Carla P. Bruniera ${ }^{2}$
}

Recebido em 27/06/2010. Aceito em 03/09/2010

RESUMO - (Disposição de dois nomes em Almeidea (Rutaceae)). O estudo dos tipos nomenclatórios no herbário P mostrou que Almeidea longifolia A. St.-Hil. (Rutaceae) é um nome substituto ilegítimo de Almeidea affinis A. St.-Hil., e este último nome é aqui considerado sinônimo heterotípico de $A$. rubra A. St.-Hil. Palavras-chave: Galipeinae, nomenclatura, taxonomia

ABSTRACT - (Disposition of two names in Almeidea (Rutaceae)). Examination of type specimens at the P herbarium showed that Almeidea longifolia A. St.-Hil. (Rutaceae) is an illegitimate substitute name for $A$. affinis A. St.-Hil. The latter name is proposed here as a heterotypic synonym of $A$. rubra A. St.-Hil. Key words: Galipeinae, nomenclature, taxonomy

Almeidea A. St.-Hil. belongs to the Neotropical tribe Galipeeae (replacing Cusparieae; Kallunki \& Pirani 1998), subtribe Galipeinae (Rutaceae). In Brazil, the five species of the genus occur in the coastal Atlantic rain forest, from southern Bahia to Paraná, including Espírito Santo, Rio de Janeiro, São Paulo, and eastern Minas Gerais (Silva 1988). One species, A. rubra A. St.-Hil., is also found in forested areas in the province of La Paz, Bolivia. A phylogenetic study and taxonomic revision of the genus is underway and examination of the type collection of A. longifolia A. St.-Hil. showed that this name is an illegitimate substitute name for A. affinis A. St.-Hil.; the latter name is proposed here as a heterotypic synonym of $A$. rubra.

Almeidea rubra A. St.-Hil., Bull. Sci. Soc. Philom. Paris 10: 130. 1823. Type: [Brazil, Rio de Janeiro] In Monte Babylonia, prope R.J., A. Saint-Hilaire s.n. (holotype $\mathrm{P}$ n.v. photo!).

Almeidea affinis A. St.-Hil., Bull. Sci. Soc. Philom. Paris 10: 130. 1823 (Sep). Almeidea longifolia A. St.-Hil., Mém. Mus. Hist. Nat. 10: 359. 1824 (Mar-Apr, $c f$. Margadant 1968; as '1823'), illeg. substitute name. Type: [Brazil] Bois vierge à Uba [Rio de Janeiro], A. Saint-Hilaire s.n. (holotype P n.v. photo $\mathrm{P}$ !; isotype $\mathrm{P}$ n.v. photo P!). Syn. nov.

The original descriptions of $A$. affinis and A. longifolia consist of only short diagnoses with no indication of the material upon which they were based. Two type specimens in the P herbarium show, however, that they were based on the same material. On each of the sheets, the name Almeidea affinis is written, the epithet is crossed out, and 'longifolia' is written in its place. The handwriting on the specimens matches examples of that of Saint-Hilaire (Burdet 1979), indicating that he himself changed the name. The name A. longifolia was subsequently used in all botanical works where this species is treated (e.g., Candolle 1824; Engler
1874, 1931; Albuquerque 1968; Silva 1998; Pirani 2009), but because it is an illegitimate substitute name for $A$. affinis and nomenclaturally superfluous according to article 52.1 of the ICBN (McNeill et al., 2006), it must be rejected.

Saint-Hilaire (1823) distinguished $A$. affinis from $A$. rubra by its more obtuse petals and its pubescent (rather than glabrous) pedicels. However, examination of the types of both names and of other collections of Almeidea deposited in the herbaria cited in the acknowledgments showed that these characters are variable and cannot be used to distinguish the two species. As both names, $A$. affinis and A. rubra, were published in the same work (and on the same page), we choose the latter to represent this species because of its widespread use in the literature and on herbarium specimens, making $A$. affinis a heterotypic synonym of $A$. rubra.

\section{Acknowledgments}

The authors thank the curators of the herbaria visited during the study (ALCB, BHCB, CEPEC, HRCB, HUEFS, MBML, NY, RB, SP, SPF, UEC) and for the gifts of important collections of Rutaceae to SPFR; Jacquelyn A. Kallunki (New York Botanical Garden) for her critical reading of the manuscript and for providing important literature, and Pedro Dias de Oliveira for his comments on the text; Inês M. Silva for the images of types from P; and to Fundação de Amparo à Pesquisa do Estado de São Paulo and Conselho Nacional de Desenvolvimento Científico e Tecnológico for financial support (Fapesp grants \#2006/03170-0 and 2007/06336-0, and CNPq grant \#307627/2009-8, respectively).

\section{References}

Albuquerque, B.W.P. 1968. Rutaceae do Estado da Guanabara. Anais da Academia Brasileira de Ciências 40(4): 499-530.

Burdet, H.M. 1979. Auxilium ad botanicorum graphicem. Genève, Conservatoire et Jardin Botaniques.

Candolle, A.P. 1824. Rutaceae. Pp. 709-732. In: Candolle A.P. (ed.). Prodromus systematis naturalis regni vegetabilis, Vol. 1. Paris, Treuttel \& Wurtz.

Engler, H.G.A. 1874. Rutaceae. Pp. 75-196. In: Martius C.F.P. \& Eichler A.G. (eds). Flora brasiliensis, Vol. 12, pars 2. Monachii, Typographia Regia.

\footnotetext{
1 Universidade de São Paulo, Faculdade de Filosofia, Ciências e Letras de Preto, Departamento de Biologia, Ribeirão Preto, SP, Brazil

2 Universidade de São Paulo, Instituto de Biociências, Departamento de Botânica, São Paulo, SP, Brazil

Author for correspondence: groppo@ffclrp.usp.br
} 
Engler, H.G.A. 1931. Rutaceae. Pp. 187-359. In: Engler A. \& Prantl K. (eds). Die natürlichen Pflanzenfamilien, Vol. 19a. Ed. 2. Leipzig, Wilhelm Engelmann

Kallunki, J.A. \& Pirani, J.R. 1998. Synopses of Angostura Roem. \& Schult. and Conchocarpus J. C. Mikan (Rutaceae). Kew Bulletin 53(2): 257-334

Margadant, W.D. 1968. Early bryological literature. Pittsburgh, Hunt Botanical Library.

McNeill, J.; Barrie, F.R.; Burdet, H.M.; Demoulin, V.; Hawksworth, D.L.; Marhold, K.; Nicolson, D.H.; Prado, J.; Silva, P.C.; Skog, J.E.; Wiersema, J.H. \& Turland, N.J. 2006. International code of botanical nomenclature (Vienna Code). Regnum vegetabile 146. Liechtenstein, A.R.G. Gantner Ruggell Verlag.

Pirani, J.R. 2009. Rutaceae. Pp. 461-464. In: Stehmann, J.R.; Forzza, R.C.; Salino, A.; Sobral, M.; Costa D.P. \& Kamino L.H.Y. (eds). Plantas da floresta atlântica. Rio de Janeiro, Instituto de Pesquisas Jardim Botânico do Rio de Janeiro.

Saint-Hilaire, A. 1823. Description des principaux genres nouveaux et des espèces nouvelles de la Flore du Brésil. Bulletin des Sciences, par la Société Philomatique 10: 129-132.

Silva, I.M. 1998. Revisão taxonômica do gênero Almeidea St.-Hilaire (Rutaceae). M.Sc. dissertation. Universidade Federal do Rio de Janeiro.

Versão eletrônica do artigo em www.scielo.br/abb e http://www.botanica.org.br/acta/ojs 